\title{
Money Demand Function for Nepal: An Empirical View from Expenditure Component
}

\author{
Pujan Adhikari \\ Lecturer of economics, Patan Multiple Campus, Tribhuvan University, Nepal \\ Email: padhikari85@gmail.com
}

\begin{abstract}
This paper examines the long run and short-run dynamics relationship between broad money, consumption expenditure, capital stock and interest rate in Nepal over the period of 19752017. This paper employs ARDL bound testing approach for co-integration between the broad money demand and its determinants. Result reveals the evidence of cointegration among the variables. The empirical results show that the demand for money is affected by the interest rate and final consumption expenditure both in the long run and short-run. However, the gross fixed capital formation has no impact on demand for money in the long-run and short-run as well. On contrast, interest rate is positively associated with Broad money demand, which is not consistent with theoretically. Positive association of money demand with interest rate shows that demand for money function is instability in Nepal. Thus, this study suggests that policy maker to correct price fluctuation through the control of various expenditure components, particularly, real final consumption expenditure might be an important strategy in the long run. However, the gross fixed capital formation has no impact on demand for money in the long-run.
\end{abstract}

Keywords: money demand, expenditure component, ARDL bound testing

\section{INTRODUCTION}

The stability of the demand for money is crucial in policy analysis because monetary policy operates through the changes in the stock of money Ghatak (1995). The stability of the money demand function is important, that is the money supply will have influence on real variables and the central bank control money supply as an effective macroeconomic policy. For the effective implementation of monetary policy, stability of money demand highly matters Hamori and Tokihisa (2001). The demand function for money helps to ascertain the liquidity needs of the economy (Handa, 2009). As a result, it is exigent for the policy makers to understand the factors that determine this function and the existence of a stable long-run relationship between these factors and the money stock. Several factors affect the stability of money demand in a given country (Budha, 2011). In this context, an effectiveness of the monetary policy of demands first to test the stability of money demand function. 
Especially after the adoption of financial liberalization in the 1980s, there might have been the forces that might have caused the instability in money demand function and rendered the monetary policy ineffective. In such a case, the stability issue of the money demands function needs an intense focus for justifying the working of the monetary targeting strategy (Khan \& Wadud, 2003).

This paper seeks to examine empirically the long-run relation of broad money demand and its determinants in Nepal. This study considers various components of final expenditure demand as determinants that are final consumption goods, expenditure on investment goods and interest rate.

\section{LITERATURE REVIEW}

Theoretically, Keynes (1936) highlighted the transaction, precautionary and speculative motives for holding money. Friedman $(1956,1968)$ is partly Keynesian and partly non Keynesian, that is neglects completely Keynes classification of the motives for holding money and treated the total demand for money as the part of the balance sheet or portfolio of assets. (Baumol 1952; Tobin 1956) introduced interest rate as one of the explanatory variables in the transactions demand for money.

The empirical works on its stability and estimation have received increasingly attention among developed and developing countries, because of its relevant monetary policy implications, (Tang, 2004). Nchor and Adamec (2016) examined demand for broad money and its stability in Ghana by considering Gross domestic product, interest rate in Ghana over the period 1990 to 2014 using an error correction model, ECM to determine factors that influence real money aggregation. The study estimated the results using two set of variables for real demand for money, M1 and M2. The results show that, GDP affects the level of demand for money in the long run while the interest rate affects it in the short run. The error correction term in each of the cases shows that, $18 \%$ of deviations in the real demand for money are corrected annually. In addition, the CUSUM tests of parameter stability showed that, the money demand function was stable over the period and the Chow test indicated that there were no structural breaks. Baharumshah et al.(2009) study documented about demand for broad money (M2) in China that long run relationship exists between M2 and its determinants: real income, inflation, foreign interest rates and stock prices using the auto regressive distributed lag (ARDL) cointegration integration framework.

Some empirical studies based on various components of real expenditure were carried on over the conventional theory of money demands related to scale variables such as income and interest rate. Tang (2004) estimated a money demand function based on Japanese quarterly data over the period between the first quarter of 1973 and the second quarter of 2000. This study showed that the demand for broad money, as defined by the sum of M2 monetary aggregate and certificates 
of deposit, has been stable during that period. The study found the existence of a long-run relationship between the demand for broad money, the final consumption expenditure, the expenditure on investment goods, the exports expenditure, the deposit rate and the government bond yield rate.

Salha and Jaidi (2014) estimated a money demand function in Tunisia based on annual data ranging between 1979 and 2011 and the ARDL bounds testing approach, results revealed that evidence of cointegration between the broad money demand and its determinants, namely the final consumption expenditure, the expenditure on investment goods, the export expenditure and the interest rate. In addition, the error correction model showed that the demand for money is only affected by the interest rate and the expenditure on investment goods in the short-run, while in the long-run the final consumption expenditure and the interest rate represent the major money demand determinants.

Nchora and Adameca (2016) examine the demand for broad money and its stability in Ghana .Error correction model (ECM) was used to determine the factors that influence real money aggregate in Ghana from 1990 to 2014.The results show that, GDP affects the level of demand for money in the long run while the interest rate affects it in the short run. The CUSUM tests of parameter stability showed that the money demand function was stable over the period and the Chow test indicated that there were no structural breaks.

In Nepalese context, a number of empirical exercises have been carried out on the stability and estimation of Nepalese money demand function. Poudel (1987) and Khatiwada (1997) estimated a money demand function using OLS method considering GDP and interest rate and found stable demand for money function. Kharel and Koirala (2010) also used Johansen MLE to examine the stability of money demand functions on Nepalese data over the periods 19752010 and admitted stable money demand function with real GDP and interest rate.

A few literature studies found the cointegration method used for examining the stability of money demand function in Nepalese context. Budha (2011) analyzed the money demand function for Nepal during the period of the FY 1997 to 2009 using annual data. While applying the cointegration test, he finds the existence of the longrun relationship between real money balances and its determinants. Bhatta (2011) also examined the long run and short run demand for money functions and their stability issues for Nepal using the annual data set of 1975-2009. He finds the long run cointegration relationship is existing among the demand for real money balances, real GDP and interest rate in case of both narrow and broad monetary aggregates.

This previous studies of Nepalese demand for money is related to scale variables such as income and domestic interest rate. However, none of the existing study addressed 
the impacts of various components of final consumption expenditure on the Nepalese demand for money. Thus, this paper investigates dynamic relationship between the final consumption expenditure, capital and interest rate on money demand.

\section{ECONOMETRIC METHODOLOGY}

Generally, the conventional theory of money demand indicates that scale variables such as income and domestic interest rate or inflation (opportunity cost variables) determines the money demand, which can be expressed as

$$
\frac{M}{P}=f(Y, I)
$$

where $\mathrm{M} / \mathrm{P}$ represents money demand which depends on real income $(\mathrm{Y})$ and Interest rate (i) Most of the relationships cited in previous section show that there positive relationship between real income and money demand for given the price level and rise in the interest rate reduces the money demand.

This study incorporates real consumption and investment expenditure components of real income, and interest rate as other explanatory variable, following Tang $(2002,2004)$. The long run money demand function for broad money is expressed as follows:

$$
M d / p=f(R F C E, R G F C F, r)
$$

where $\mathrm{Md}$ is nominal broad money demand, $\mathrm{P}$ is price, RFCE represents real final consumption expenditure, RGFCF is real gross final capital formation and $\mathrm{r}$ stands for interest rate. Thus, model in the log linear form by adding constant and error terms is

$$
M d_{t}=\beta_{0}+\beta_{1} \ln R F C E_{t}+\beta_{2} \ln R G F C F_{t}+\beta_{3} r_{t}+u_{t}
$$

where $\beta 0$ is constant term, $U_{t}$ is a random error and $\ln$ is natural logarithmic transformation.

The opportunity cost of holding money (interest rate) is in absolute form rather than transforming into logarithmic form as suggested by Ghatak (1995). Rate of interest on lending has been used as a proxy for long term interest rate interest rate as data are not available for long term fixed deposit rate for the whole study period. Real rate of interest on lending is defined as nominal interest rate on lending minus expected rate of inflation. The use of $\mathrm{t}$-bill rate or long term bond rate is irrelevant as these instruments are not a significant part of asset portfolios. Various components of real expenditures such as final consumption expenditure on goods and services and investment expenditure have been incorporated as a component of real income. Real broad money is defined by the broad money stock divided by CPI Bhatt (2011). One of the major expenditure component; export has not been used due to unavailability of data. 
The intuition of this desegregation of macro components (real income) is that use of a single scale variable in the aggregate money demand function would lead to aggregation bias. In addition, this method is trying to capture the different impacts of expenditure classification on money demand as suggested by Tang (2002). This study investigates the different domestic demand components on broad money behavior. Based on conventional theories, sign of parameter of expenditure component, is expected to be positive whereas parameter of the interest rate is expected to be negative.

ARDL modeling to co-integration, techniques developed by Pesaran and Shin (1999) has been widely applied for examining the stability of money demand function. This study also applies ARDL technique as opposed to the standard approaches to cointegration by Engle and Granger and Johansen (1991). The ARDL model technique overcome the criticism of exclusion of multivariate analysis under Engle and Granger co- integration test and difficulty in interpretation when more than one co- integrating vectors exist in the model and sensitivity with numbers of lag selection with Johansen techniques.

As explained by Nepal and Paija (2019), ARDL techniques has the following key characteristics: (i) the co-integration relationship is estimated using OLS estimation, which is conducted after choosing the appropriate lag order for the model; (ii) notwithstanding the Johansen and Juselius (1990) approach, this technique remains statistically significant irrespective of the nature of the variables' integration order , i.e., I (0), I (1) or mutual co-integrated; and finally, it is imperative to mention that (iii) the test is necessary and valid for small and finite sample sizes. The bound test is a test of coefficient by performing Wald test on following unrestricted error correction model (ECM):

$$
\begin{aligned}
& \Delta \operatorname{lnMdt}=\beta 0+\sum_{i=1}^{n} \beta 1 i \Delta M d t-1+\sum_{i=1}^{n} \beta 2 i \Delta R F C E t-1+\sum_{i=1}^{n} \beta 3 i \Delta R F C E t-1+ \\
& \sum_{i=1}^{n} \beta 4 i \Delta r t-1+\beta 6 \ln R F C E t-1+\beta 7 \ln R G F C E t-1+\beta 8 r t-1+u t
\end{aligned}
$$

where $\Delta$ is the first difference operator, $\mathrm{Md}_{\mathrm{t}}$ represents real broad money balances and $u_{t}$ is disturbance term. Similarly, $\beta_{1}, \beta_{2}, \beta_{3}, \beta_{4}$ represents the short run dynamics and $\beta_{5}$, $\beta_{6}, \beta_{7}, \beta_{8}$ are the long run coefficients.

To examine whether the long run equilibrium relationship exists between lnMdt, lnRFCE $\operatorname{lnRGFCF}$ and $\mathrm{r}$, Bounds test (F-version) for co-integration is carried out s proposed by Pearson and Shin (1999). The F -test is a test where absence of cointegration is null hypothesis and presence of co integration as an alternative hypothesis, both denoted as: 
H0: $\beta_{5}=\beta_{6}=\beta_{7}=\beta_{8}=0$.i.e. the absence of co integration relationships

H1: $\beta_{5}=\beta_{6} \neq \beta_{7} \neq \beta_{8} \neq 0$.i.e. the existence of co integration relationships

\section{Data}

This paper examines the long run inter relationships between broad money demand balances in a multivariate framework with final consumption expenditure, capital stock and interest rate for Nepal over the period 1975 to 2017. All variables used in this study is extracted from the data set maintained by World Development Indicators (WDI), World Bank.

Table 1: Variable Details

\begin{tabular}{ll}
\hline Variables Name & Details \\
\hline $\mathrm{md}_{\mathrm{t}}$ & $\begin{array}{l}\text { Real Broad money stock defined by the broad money stock } \\
\text { divided by GDP Deflator, 2010=100) (local currency in billions) }\end{array}$ \\
$\mathrm{RFCE}$ & $\begin{array}{l}\text { Real final consumption expenditure divided by divided by } \\
\text { GDP Deflator, 2010=100) }\end{array}$ \\
$\mathrm{Rr}_{\mathrm{t}}$ & $\begin{array}{l}\text { Real rate of interest is the lending rate which is adjusted for } \\
\text { inflation } \\
\mathrm{RGFCF}\end{array}$ \\
& $\begin{array}{l}\text { Real gross final capital formation divided by divided by GDP } \\
\text { Deflator, 2010=100) }\end{array}$ \\
\hline
\end{tabular}

Table 2: Descriptive Statistics and Correlation Matrix

\begin{tabular}{lllll}
\hline Statistic & $\operatorname{lnMd}$ & $\operatorname{lnRFCE}$ & $\operatorname{lnRGFCF}$ & $\mathrm{Rr}$ \\
\hline Mean & 2.148 & 2.480 & 1.827 & 2.354 \\
Median & 2.120 & 2.478 & 1.879 & 3.363 \\
Maximum & 2.936 & 2.868 & 2.421 & 18.214 \\
Minimum & 1.277 & 2.116 & 1.290 & -15.600 \\
Std. Dev. & 0.463 & 0.235 & 0.300 & 6.052 \\
Skewness & 0.015 & 0.015 & -0.008 & -0.700 \\
Kurtosis & 1.899 & 1.740 & 2.088 & 4.845 \\
J-B Test & 2.172 & 2.845 & 1.489 & 9.611 \\
Probability & 0.338 & 0.241 & 0.475 & 0.008 \\
\hline Correlation & & & & \\
lnMd & 1 & & & \\
lnRFCE & 0.996 & 1 & & \\
lnGFCF & 0.991 & 0.988 & 1 & \\
Rr & -0.158 & -0.192 & -0.174 & 1 \\
\hline
\end{tabular}

Note: The J-B refers to the Jarque - Bera normality test. 
Table2 shows the descriptive statistics and correlations among the variables. The mean of final consumption expenditure, Gross fixed capital formation and interest rate is $2.480,1.827$ and 2.354, respectively. Standard deviation of all variable is significant during the study period. Final consumption expenditure and Gross final capital formation are positively associated with money demand whereas negative association exists between interest rate and money demand.
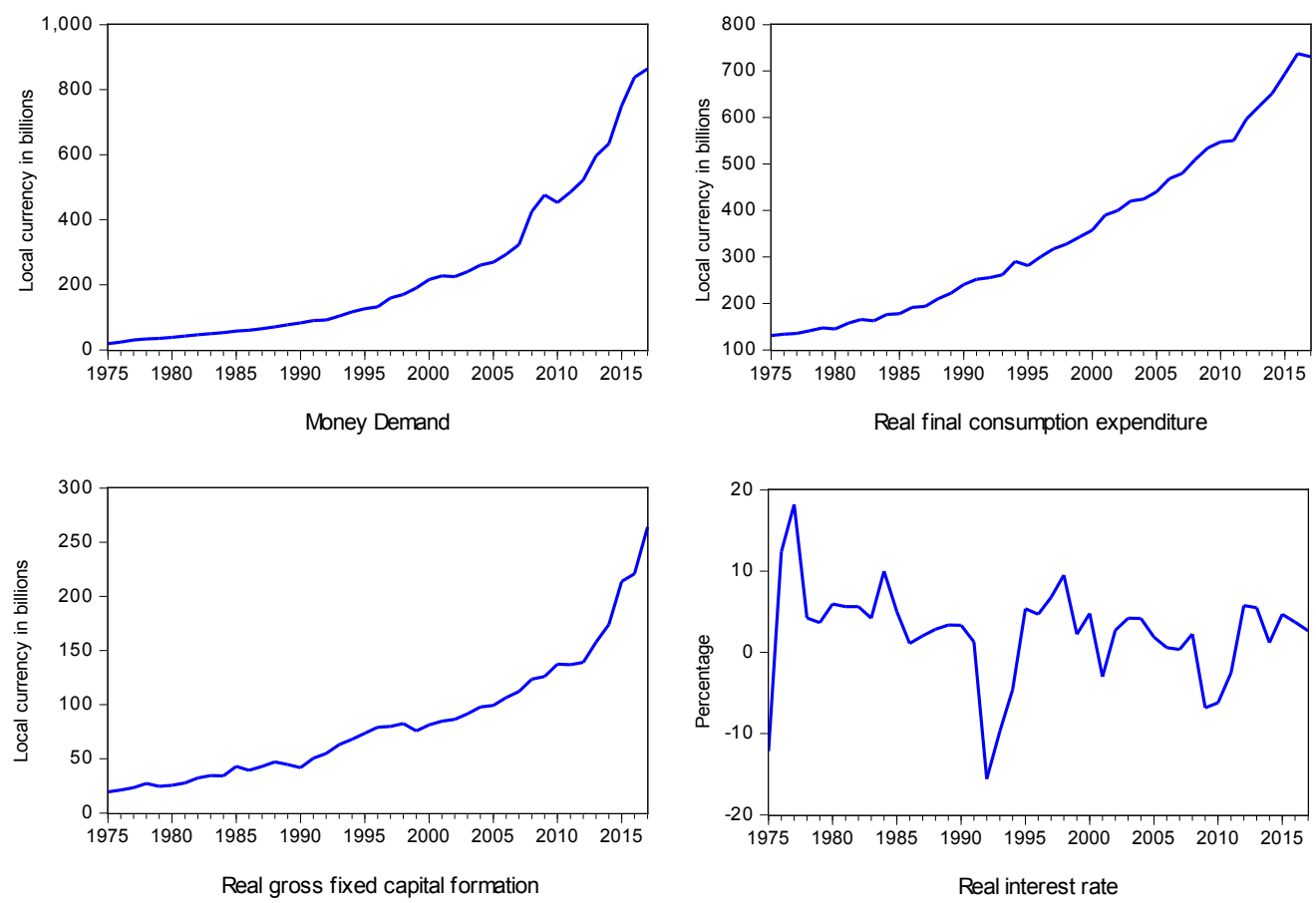

Figure 1. Data series used in the study.

Figure 1 shows the time series plots of all variables incorporated in this study. Money demand, real final consumption expenditure and real gross fixed capital formation shows upward trend. Real interest rate shows the fluctuation tendency over the period.

\section{RESULT AND DISCUSSION}

Auto Regressive Distributed Lag modeling (ARDL) has been followed for the analysis of money demand function and confirms the presence or absence of long-run and short-run equilibrium relationships. The unit root tests indicate the maximal order of integration of the time series. The bounds test justifies the existence of the co integration or long- run relationships among variables in the model. 
Table 3: Results of Augmented Dickey-Fuller (ADF), Phillips Perron (P-P) Unit Root Test

\begin{tabular}{|c|c|c|c|}
\hline Panel I & Variable & ADF & $p-p$ \\
\hline \multicolumn{4}{|l|}{ Level } \\
\hline \multirow[t]{4}{*}{ Intercept } & $\operatorname{lnMd}$ & $-1.114(0)$ & -1.161 \\
\hline & $\ln R F C E$ & $0.607(1)$ & 0.490 \\
\hline & $\ln R G F C F$ & $0.171(0)$ & 0.171 \\
\hline & $\mathrm{Rr}$ & $-4.708^{* * *}(0)$ & $-4.708^{* * *}$ \\
\hline \multirow[t]{4}{*}{ Intercept and Trend } & $\ln \mathrm{Md}$ & $-2.539(0)$ & -2.539 \\
\hline & $\ln R F C E$ & $-4.775^{* *}(0)$ & $-4.192^{* *}$ \\
\hline & $\ln R G F C F$ & $-2.400(0)$ & -2.454 \\
\hline & $\mathrm{Rr}$ & $-5.063^{* * *}(0)$ & $-5.149^{* * *}$ \\
\hline \multicolumn{4}{|c|}{ Panel II: First Difference } \\
\hline \multirow[t]{4}{*}{ Intercept } & $\operatorname{lnMd}$ & $-5.775^{* * *}(0)$ & $-9.129^{* * *}$ \\
\hline & $\ln R F C E$ & $-9.905^{* * *}(0)$ & $-10.178^{* * *}$ \\
\hline & $\ln R G F C F$ & $-7.642^{* * *}(0)$ & $-7.641^{* * *}$ \\
\hline & $\mathrm{Rr}$ & $-7.871^{* * *}(0)$ & $-17.073^{* * *}$ \\
\hline \multirow[t]{4}{*}{ Intercept and Trend } & $\operatorname{lnMd}$ & $-5.685^{* * *}(0)$ & $-8.543^{* * *}$ \\
\hline & $\ln R F C E$ & $-9.856^{* * *}(0)$ & $-10.143^{* * *}$ \\
\hline & lnRGFCF & $-7.585^{* * *}(0)$ & $-7.588^{* * *}$ \\
\hline & $\mathrm{Rr}$ & $-7.721^{* * *}(0)$ & $-24.376^{* * *}$ \\
\hline
\end{tabular}

Note: ${ }^{* * *},{ }^{* *}$, and ${ }^{*}$ represent $1 \%, 5 \%$, and $10 \%$ level of significance, respectively. Parenthesis bracket represents lag order.

Before testing the presence of long run relationships between the broad money demand and its determinant, we have to analyses the stationary properties of variables associated in the model. For this, ADF (Augmented Dickey-Fuller), P-P (PhillipsPerron) test has been used as a pre-requisite for integration. Table 3 shows the results of the ADF and P-P unit root test. The unit root tests performed at level and at first difference with an intercept and an intercept and trend.

The test shows that interest rate variable is stationary at level, moreover, consumption expenditure also seems stationary at trend and intercept at level. However, others variables are stationary at the first difference. Therefore, our variables show mixed orders of integration (i.e.,I(1) or I(0)), as reported in Table 3, supports the application of ARDL approach. Hence, the ARDL bounds testing approach is employed to test the existence of cointegration relationships.

In Table 4, we report $\mathrm{F}$-statistics calculated when targeted variable is mentioned as a dependent variable. As mentioned previously, the bounds testing approach to 
cointegration involves the comparison of the F-statistics against the tabulated critical value bounds.

Table 4: ARDL Bounds Test

\begin{tabular}{llll}
\hline Dependent variable & AIC Lag & F-stat. & Outcome \\
\hline $\boldsymbol{F}_{l n M}(\ln M \mid \ln R F C E, \ln R G F C F, \ln r)$ & $(1,0,0,0)$ & $3.911^{*}$ & Cointegration \\
Critical value & $\mathrm{I}(0)$ & $\mathrm{I}(1)$ & \\
\hline 1 percent significance level & 4.29 & 5.61 & \\
5 percent significance level & 3.23 & 4.35 & \\
10 percent significance level & 2.72 & 3.77 & \\
\hline
\end{tabular}

Note: ${ }^{* * *},{ }^{* *}$ and ${ }^{*}$ indicate $1 \%, 5 \%$ and $10 \%$ significance at level, respectively.

The result in Table 4 suggest that the calculated F-statistic is 3.911* $F_{l n M}(\ln M \mid \ln R F C E, \ln R G F C F, \ln r)$, which is bigger than upper bound critical value of Pesaran et al. (2001) at the 10 percent significance level. It denotes that the null hypothesis of no cointegration is rejected. Hence, the long-run cointegration relationship among the variable when demand for money variable is considered as a dependent variable.

Since a co-integration relationship is identified, this study proceeds to estimate equation (3) following the lag specification 1, 0, 0, 0 in Table 5 .

Table 5: ARDL Long-run Estimation

\begin{tabular}{lllll}
\hline Variable & Coefficient & Std. Error & t-Statistic & Prob. \\
\hline $\ln R F C E$ & $1.667^{* * *}$ & 0.242 & 6.893 & 0.000 \\
$\ln R G F C F$ & 0.228 & 0.191 & 1.194 & 0.240 \\
$\operatorname{Rr}$ & $0.005^{* *}$ & 0.002 & 2.303 & 0.027 \\
DUM & $-0.110^{*}$ & 0.062 & -1.769 & 0.085 \\
C & $-2.339^{* * *}$ & 0.258 & -9.074 & 0.000 \\
\hline
\end{tabular}

Note: ${ }^{* * *},{ }^{* *}$ and ${ }^{*}$ indicate $1 \%, 5 \%$ and $10 \%$ significance at level, respectively.

Interestingly, the long-run estimation of the ARDL framework reveals that the final consumption expenditure and the interest rate re found to be significant for money demand in the long-run. However, the gross fixed capital formation has no impact on demand for money in the long-run. The estimated elasticities for final consumption expenditure (RFCE) is 1.669 , and 0.005 for the interest rate. However, interest rate elasticity is positive which is not consistent theoretically (just opposite to Keynesian 
view), we can conclude that demand for money function is instable in Nepal, which is a consequences of regime changes. Thus, we addressed regimes swift, we incorporate dummy variable. A number of empirical studies find similar results (e.g., Nachega, 2001 for Cameroon; Nell, 2003 for South Africa; Nwafor et al. 2007 for Nigeria; and Kumar \& Seem, 2009 for Nepal).

This study investigates the short-run impact of the money demand and its determinants along with an error correction model (ecm) using eq. 4. Applying the error-correction model allows checking the short-run elasticities and measuring the speed of adjustments to the long-run equilibrium via the error-correction term. A negative and statistically significant coefficient on this term is an indicator of the existence of cointegration. Similar to the long-run phenomena, an elasticities of final consumption and interest rate are found statistically significant in the short-run, but no significance in capital, which means that there is no impact of capital in money demand in the short-run.

Table 6: ARDL Short-Run Estimation

\begin{tabular}{lllll}
\hline Variable & Coefficient & Std. Error & t-Statistic & Prob. \\
\hline$\Delta \ln R F C E$ & $0.610^{* * *}$ & 0.146 & 4.174 & 0.0002 \\
$\Delta \ln R G F C F$ & 0.084 & 0.075 & 1.107 & 0.2756 \\
$\Delta \mathrm{Rr}$ & $0.002^{* *}$ & 0.001 & 2.891 & 0.0065 \\
$\Delta \operatorname{lnDUM}$ & $-0.040^{*}$ & 0.020 & -1.999 & 0.0531 \\
$\mathrm{ECT}_{+-1}$ & $-0.366^{* * *}$ & 0.080 & -4.549 & 0.0001 \\
\hline
\end{tabular}

Note: ${ }^{* *},{ }^{* *}$ and ${ }^{*}$ indicate $1 \%, 5 \%$ and $10 \%$ significance at level, respectively.

The estimated elasticities for final consumption is 0.610 and 0.002 percent for interest rate (Table 6). The negative and highly significant coefficient of the error correction model signifies that short-run disequilibrium adjusts by $37 \%$ annually towards the long-run equilibrium. The positive sign of the interest rate in the money demand function is similar to the findings of Narayan et al. (2009) who estimated a money demand function for a panel of five Asian countries and failed to find a stable money demand function for Nepal. Granger Causality suggests Domestic nominal interest rate produces a positive and statistically insignificant relationship is observed for Nepal.

Table 7: Diagnostic Test of ARDL Model

\begin{tabular}{|c|c|c|c|c|c|}
\hline & $\begin{array}{l}\text { Test- } \\
\text { statistic }\end{array}$ & P-value & & $\begin{array}{l}\text { Test- } \\
\text { statistic }\end{array}$ & P-value \\
\hline R-squared & 0.998 & & R-bar-squared & 0.997 & \\
\hline Serial correlation $\chi^{2}(1)$ & 0.308 & 0.579 & Normality & 14.770 & 0.136 \\
\hline Functional form $\chi^{2}(1)$ & 2.084 & 0.149 & Heteroscedasticity $\chi^{2}(1)$ & 4.079 & 0.538 \\
\hline
\end{tabular}


Equation (4) has succeed several diagnostic tests that support the validity of the model. The values of $R^{2}$ and Adjusted $R^{2}$ are 0.998 and 0.997 , respectively, which denotes that the model is well fitted. Table 7 shows the fitted model does free from serial correlation, functional error or heteroscedasticity problems. Moreover, model is also normally distributed. The CUSUM (cumulative sum) and CUSUMQ (cumulative sum of squares) in Figures 2 and 3 from a recursive estimation of the model also indicate the model is stable, as the residuals are within the critical bounds at the $5 \%$ significance level.

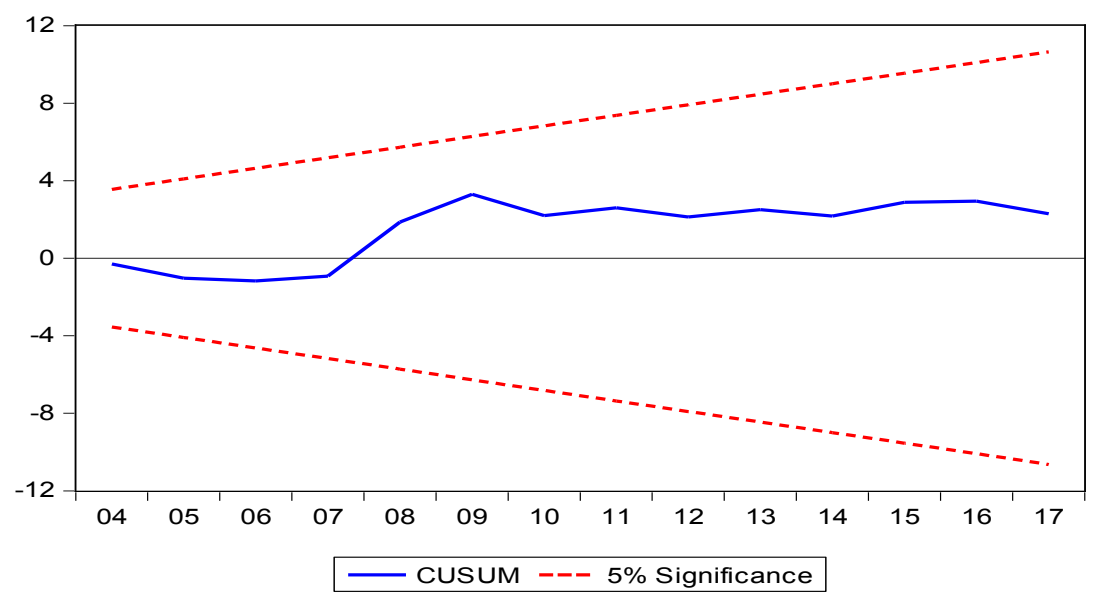

Figure 2 : Plot of Cumulative Sum of Recursive Residuals

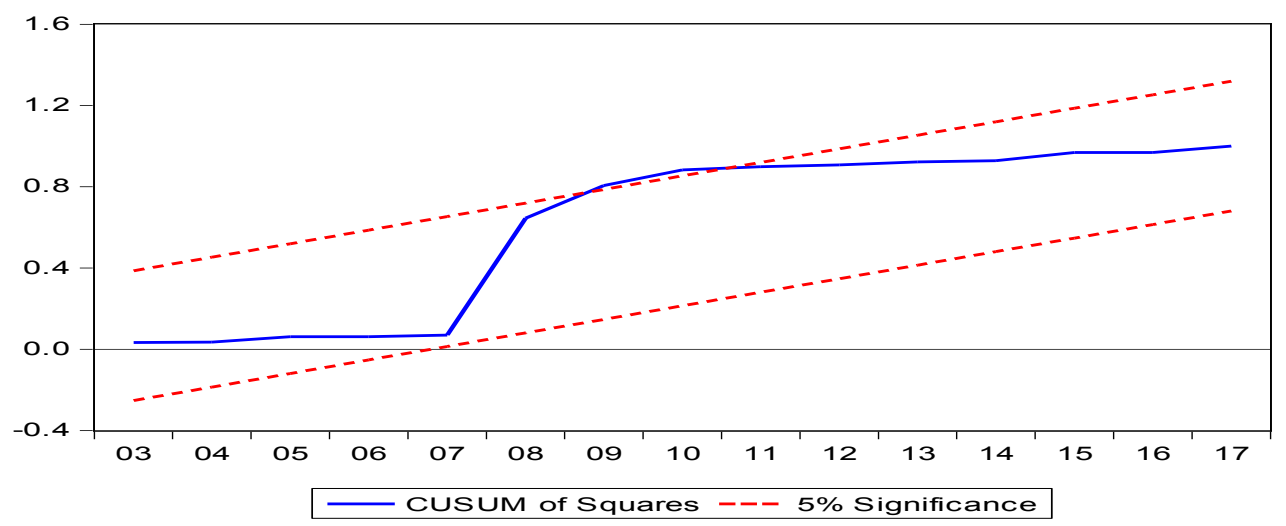

Figure 3: Plot of Cumulative Sum of Squares of Recursive Residuals 


\section{CONCLUDING REMARKS}

This paper empirically examines the long run relationship and short-run dynamics between real broad money demand and its determinants. This study investigated the impact of expenditure components on real broad money demand by splitting into real final consumption expenditure and real gross fixed capital formation, unlike the major previous studies based on scale variables. Using the ARDL bounds testing technique, the result shows the long run cointegration relationship among the variables when demand for money variable is considered as a dependent. Interestingly, the long-run estimation of the ARDL framework reveals that the final consumption expenditure and the interest rate were found to be significant for money demand in the long-run. However, the gross fixed capital formation has no impact on demand for money in the long-run.

The interest rate is elasticity is positive which is not consistent with theoretically, we can conclude that demand for money function is instability in Nepal, which is a consequences of regime changes. This study also investigates the short-run impact of the money demand and its determinants along with an error correction model (ECM). Applying the error-correction model allows checking the short-run elasticities and measuring the speed of adjustments to the long-run equilibrium via the errorcorrection term. With respect to the stability of the money demand function, the CUSUM (cumulative sum) and CUSUMQ (cumulative sum of squares) indicate the model is stable, as the residuals are within the critical bounds at the $5 \%$ significance level.

These findings have important implications on policy formulation in Nepal, monetary targeting policy to correct price fluctuation through the control of various expenditure components, particularly, real final consumptionmight be an important strategy in the long run. However, the gross fixed capital formation has no impact on demand for money in the long-run. In the context of interest rate, it is found that interest rate is positively associated with real broad money demand, which is not theoretically consistent with the Keynesian view.

\section{References}

Baumol, W. (1952). The transaction demand on cash: An inventory theoretic approach. Quarterly Journal of Economics, 66, 545-556.(1).

Budha, B. (2011). An empirical analysis of money demand function in Nepal. NRB Economic Review.Kathmandu, Nepal: Nepal Rastra Bank (NRB). 
Friedman, M. (1956). The quantity theory of money - a restatement. In M. Friedman (Ed.), Studies in the quantity theory of money. Chicago, IL: University of Chicago Press.

Ghatak, S.( 1995). Monetary economics in developing countries, 2nd ed. New York: St. Martin's Press,

Hamori, S., \& Tokihisa, A.(2001). Seasonal cointegration and the money demand function: Some evidence from Japan. Applied Economics Letters, 8, 305-310.

Handa, J. (2009). Monetary economics. New York: Rutledge Taylor \& Francis Group.

https://www.nrb.org.np/ecorev/pdffiles/vol23-1_art4.pdf ( ). An empirical analysis of money demand function in Nepal.

Johansen, S. (1991). Estimation and hypothesis testing of cointegration vectors in Gaussian vector autoregressive models. Econometrica 59, 1551-1580.

Johansen, S., \& Juselius, K. (1990). Maximum likelihood estimation and inferences on cointegration with applications to the demand for money. Oxford Bulletin of Economics and Statistics, 52,169-210.

Khan, M.A., \& Wadud, M.A. (2003). Monetary mechanism in Bangladesh: A cointegration and error correction modeling approach. A Paper presented at the 2nd European Integration and Banking Efficiency Workshop held on October 30-31, 2003 at Lisbon, Portugal.

Kharel, R.S., \& Koirala, T. P. (2010). Modeling demand for money in Nepal. NRB Working Paper.

Khatiwada, Y. R. (1997). Estimating the money demand in Nepal: Some empirical issues, Economic Review, Occasional Papers, NRB No.9.Baluwatar ,Kathmandu: Nepal Rastra Bank.

Nachega, J. (2001). A cointegration analysis of broad money demand in Cameroon. (IMF Working Paper 01/26). Washington, DC: International Monetary Fund.

Narayan, K.P, Narayan, S., \& Mishra, V. (2009). Estimating money demand functions for South Asian countries. Empirical Economics, 36, 685-696. DOI: 10.1007/ s00181-008-0219-9

Nchora, D., \&Adameca,V. (2016). Investigating the stability of money demand in Ghana. Procedia - Social and Behavioral Sciences, 220, 288 - 293.

Nell, K. S. (2003). The stability of M3 money demand and monetary growth targets: The case of South Africa. Journal of Development Studies, 39, 151-180. 
Nepal, R. , \& Paija, N. (2019). Energy security, electricity, population and economic growth: The case of a developing South Asian resource-rich economy. Energy Policy 132, 771-781.

Nwafor, F., Nwakanma, H., Nkansah, P., \& Thompson, F. (2007). The quantity theory of money in a developing economy: Empirical evidence from Nigeria. African Economic and Business Review, 5, 1-9.

Pesaran, M. H., \& Shin, Y. (1999). An autoregressive distributed lag modeling approach to cointegration analysis, in S. Strom (Ed.), Econometrics and Economic Theory in the 20th Century, The Ragnar Frisch Centennial Symposium, 1998, Cambridge University press, Cambridge.

Poudyal, S.R. (1989). The demand for money in Nepal. Economic Review, Occasional Papers, NRB No.3.

Salha, O. B., \& Jaidic, Z. (2014). Some new evidence on the determinants of money demand in developing countries: A case study of Tunisia. The Journal of Economic Asymmetries 11, 30-45.

Tang, T. C. (2004). Demand for broad money and expenditure components in Japan: An empirical study. Japan and the World Economy, 16, 487-502.

Tobin, J. (1956). The interest elasticity of transactions demand for cash. Review of Economics and Statistics, 38, 241-247. 